\title{
Transnational Perspectives: A Contemporary Examination of the African Diaspora
}

\author{
Samuel J. Byndom, University of Illinois at Urbana-Champaign \\ Brenda Nyandiko Sanya, University of Illinois at Urbana-Champaign
}

Tina M. Campt, Image Matters: Archive, Photograpby, and the African

Diaspora in Europe (Durham and London: Duke University Press, 2012).

Keri E. Iyall Smith and Patricia Leavy, eds., Hybrid Identities: Theoretical and Empirical Examinations (Chicago: Haymarket Books, 2008).

\section{Preston H. Smith II, Racial Democracy and the Black Metropolis: Housing Policy in Postwar Chicago (Minneapolis: University of Minnesota Press, 2012).}

The African diaspora has increasingly become a topic of research as many scholars engage in the study of race, identity, transnationalism, and globalization. Through the examination of Image Matters, Hybrid Identities, and Racial Democracy in the Black Metropolis, this essay attempts to explore the African diaspora in a variety of contexts, specifically focused on a visual, theoretical, and political lens situated in North America and Europe. Collectively, these three texts provide a unique perspective with which to interrogate identity and culture formation. The authors bring a nuanced understanding of global cultural identities while maintaining historical considerations; and in so doing, they add to the broader discussions on African diaspora, the history of globalization, practices of modernity, imperialism, and neoliberalism.

These works illuminate a vast array of perspectives through the preWWII frontier of Germany, the American Civil Rights Era and Great Britain from 1948-1960, and the continued experiences of African diasporic populations in the Americas. The authors demonstrate the paramount role peoples of African descent played in shaping ideology around citizenship and significant contributions to their national history. African Americans and Afro-Europeans came from a variety of class, urban, rural, political, and religious backgrounds, which correlates with their diverse identities and dynamic lifestyles. In the end, these writings create a foundation to refute conflated ideas of a monolithic Black experience. Furthermore, the diaspora framework transcends political boundaries creating a more accurate means to understanding the ways in which identity was formed in the Americas and Europe.

The authors' ability to interpret such sources as newspapers, chronicles, census lists, and an assortment of documented testimonies provided a precise 
assessment concerning the designs and practices of people across the diaspora. Above all, these books are effective in their capacity to unveil many neglected narratives that help illustrate the underpinnings of American and European societies in a global context. This essay is divided into three sections, which articulate themes of identity through visual imagery, theoretical/empirical studies, and racial political formations. Ultimately, these works interrogate the lives, relationships, and cultural identities of African Americans, Afro-Germans, and AfroBritish that can aid in our understanding of the African diaspora.

\section{Imagery}

Tina Campt's work, Image Matters: Archive, Photography, and the African diaspora in Europe, explores the vernacular image-making of Black Europeans in the early twentieth century as a means of understanding the African diaspora in Europe. Campt defines vernacular photography as a "genre of everyday image-making most often created by amateur photographers and intended as documents of personal history."1 She writes that photography, in regard to Black communities, reflects shared cultural practices and provides an individual with the freedom to present him/herself in a way that is consistent with their personal view rather than that of others or the society in which they live. Black Germans and Black Britons used vernacular photography to develop a sense of community, identity, and as a method for combating negative racial stereotypes. ${ }^{2}$ Furthermore, Campt's book is focused on understanding diaspora in Europe, particularly the ways in which Black people assimilated to the national European culture. The main aim of Campt's work is to answer the question of how Black families and communities utilized photography as a means of defining the self and their community and to forge a new identity within the context of their European home. With this backdrop, Campt attempts to answer these questions through a qualitative and interpretative analysis of two Black European communities: Black Germans during the rise of the Nazi regime and African Caribbean migrants from the West Indies in postwar Britain.

There are three conceptual frameworks structuring Campt's examination of these Black European communities: family and affiliation, vernacular seriality and circulation, and sensate photographic registers. Part One of Campt's work, "Family Matters: Sight, Sense, Touch," is divided into two chapters, "Family Touches," and "Orphaned Photos, Fugitive Images," separated by an interstitial. In this section, she presents the domestic photographs of four Black German families taken between 1900 and 1945. Readers are introduced to Hans Hauck and the Ngando brothers in chapter one while chapter two introduces Harry Davis and Fasia Jansen. This portion of Image Matters discusses the haptic qualities of the images presented through scholarship that "conceptualizes the photograph... as a tactile object and a site of material cultural practice" and 
authors who focus on the haptics of film as a "medium composed of tactile surfaces that require embodied modes of perception. ${ }^{3}$ Additionally, these images emphasize the importance of touch as a method for exploring the meaning of vernacular photography as it relates to the concept of materiality or the physicality of an image visually or through the other senses.

Campt underlines a major aspect concerning the diaspora of AfroGermans; collective migration was the exception rather than the rule, which was not the case for many other Black communities in the diaspora. Rather, the Afro-German community was formed by individual and voluntary migrations of a temporary basis. For this reason, Campt makes clear that diaspora is not a universally applicable model for understanding cultural and community formations of all Black populations. ${ }^{4}$ As such, she focuses her attention on the collective, relational practice of image making to understand diaspora rather than what can be interpreted from a single image. Campt uses an intricate analysis of the complexity of touch within and outside of the images, based on their indexical, physical, and affective characteristics, to juxtapose what is being portrayed in the image to the reality of the larger social climate of its time. She posits that the inclusion of familial objects and family members (especially family members of a different racial background) within the image should symbolize a sense of belonging; however, the social climate of the time would suggest otherwise. "Yet what these images reveal is the complex enunciatory function of the family photograph as a medium use to simultaneously claim a place of belonging and unbelonging by way of family and community affiliation." 5 Furthermore, Campt contends that twentieth-century Afro-German photography materializes race and diaspora through a term she calls performative indexicality. The subjects in the photograph are depicted as "both German and diasporic subjects."' She continues to discuss the relationship of performative indexicality to race and photography and the ability of photography to materialize race as a visible characteristic of human difference.

Part Two: Image Matters: Sight, Sound, Score, of Campt's work contains chapter three, "The Lyric of the Archive," which is preceded by an interstitial. This chapter is a collection of studio photographs of West Indian migrants taken between 1948 and 1960, which had been salvaged from Dyche Photography Studio located in Birmingham, England. This section of styled and posed images provides a necessary contrast to the more casual snapshots presented in part one.

In the postwar Caribbean community, studio photography and portraiture resignified black people's everyday image-making as an active process that created the subjects we recognize within the frame. Like ensemble performers, Caribbean migrants used studio portraiture to improvise and instantiate themselves as British subjects in relation to a 
Britishness that both actively invited their membership and participation in English society and rejected them on arrival. ${ }^{7}$

In chapter three, Campt invites readers to attune themselves not only to the visual and haptic characteristics of the images but the sonic or auditory registers that precede them. Campt states that the musicality of the photograph is not within the image but precedes it as a "constitutive and enunciating force." 8 Campt writes that including the sonic and musical registers of the images "offers dense and revealing insights into what Eve Sedgwick has called the 'finitely many possibilities' of affect and helps us to understand the photograph itself as a particularly affect-laden object and medium."9 By including a sonic appreciation of family photographs, Campt suggests that readers will gain an alternative method for understanding the ways in which Black families articulated "linkage, relation, and distinction in diaspora." 10 Furthermore, she posits that Caribbean migrants used studio photography to exemplify their identity as a member of a British society that actively invited and rejected their participation. ${ }^{11}$

Campt's thesis is based on an understanding of diaspora and diasporic movements that consists of both forced and voluntary movements of African descendents into Europe. Readers would benefit from a clear articulation and a more in-depth analysis of this broad conceptualization of diaspora, which move a way from Gilroy's black Atlantic model. ${ }^{12}$ Her discussion of Black Germany resonates with that of Jacqueline Nassy Brown who discusses Liverpool as a single European. ${ }^{13}$ For both Campt and Brown, Black Europe reveals the complexity of double diasporas, waves of migrations and in understanding locality of race and space while at the same time understanding the tensions among different Black diasporic populations living in the same place. It is curious that she decided to separate the discussion of haptic and sonic registers of an image as being part of the West Indian migrants' identity and not that of the Afro-

Germans. Campt's work at times seems superfluous and may not be as accessible to those lacking a foundational background in photography, transnationalism, and the diaspora Nonetheless, Campt masterfully incorporates updated scholarship of anthropologists, historians, archivists, photographers, and others to illustrate and substantiate her research of the diaspora in Europe. She utilizes primary sources (original photographs, oral history interviews, etc.), secondary (digital archives) and tertiary (archival information of other archivists) sources to bolster her argument as well.

Campt's work is an original contribution to the field of cultural studies, history, anthropology, and other disciplines (i.e., arts, psychology, sociology). Her work adds to the ever-growing body of knowledge concerning the African diaspora, transnationalism, and vernacular image-making. Her work is of particular importance to cultural studies within the United States because it highlights a narrative of the African diaspora that has increasingly become a subject of study 
within American academia. Using this a framework, this work offers a more holistic approach to understanding European history and melds the fields of art and social science.

\section{Theoretical \& Empirical Studies}

It is often the case that authors writing on diaspora foreground hybridity and imperialism. Hybridity offers material that elaborates and complicates, the cultures and politics of diaspora. The anthology, Hybrid Identities: Theoretical and Empirical Examinations focuses on how hybridity disconnects people from assumed cultural and biological origins. With this ambitious title, the anthology brings together essays that attempt to provide readers with theoretical and empirical perspectives that are aimed at understanding identity. Each of the seventeen chapters in this volume reveals how the use of hybridity as central category of analysis capitulates new understandings of diasporic identity and cultural formations. The editors arranged these essays into two categories, theoretical and empirical.

In the introductory chapter, which opens the theoretical discussion, Keri E. Iyall Smith hearkens back to DuBois' The Souls of Black. Folk, ${ }^{14}$ signaling the complexity and mutability of hybridity. Iyall Smith lays the groundwork for the book by introducing hybridity in relation to culture, habitus, territory, power, identity, home, assemblage, ideology, and hegemony. She writes, "hybridity has become a way to re-create and re-vision a local community, while incorporating elements of outside groups, such as the global culture."15 In this assertion, Iyall Smith suggests that what we might have considered traditional culture has been a hybrid culture all along, and that global culture is uneven and is not universal. The authors focus on themes that occupy discourses on hybridity, they are organized under the sub-topics: Hybridity and Borders, Double Consciousness, The Third Space, The Diasporized Hybrid Identity and The Internal Colony Hybrid, and Gender and the Hybrid Identity (this last category is a key contribution to the conversation on hybridity).

This anthology explores this uneven terrain and presents a survey of "the creation of new transcultural forms within the contact zone produced by colonization" 16 affects identity. Recently, hybridity appears as a convenient category signaling to 'the edge' or contact point of diaspora, describing cultural mixture where the diasporized meets the host in the scene of migration. Often viewed as twin processes, globalization and migration are often seen as the two factors that lead to the development of the more complex in the metropolitan societies of today. Speaking primarily of Korea, the Americas and New Zealand, Hybrid Identities relies on the foundational works of Paul Gilroy, Sara Ahmed, Stuart Hall, Arjun Appadurai, Homi Bhabha, W.E.B Du Bois, and James Clifford 
among others in an attempt to explore the role of the slippery category of hybridity in identity formation. ${ }^{17}$ It is in the dialogue between these works, empirical studies, and theoretical considerations, that hybridity has come to encompass a myriad of definitions relating to the mimicking, mixing and combination in the moment of cultural exchange.

In his examination of carnivals, Keith Nurse explores the role of diasporization on identity formation. Nurse successfully considers race, empire, and nation in identity formation through the examination of carnivals. In the chapter "Geoculture and Popular Culture: Carnivals, Diasporas, and Hybridities in the Americas," Nurse foregrounds how carnivals are "the consequence of the parallel process of globalization and diasporization." "18 He further argues that everything in American culture is "hybridized or the result of the confluence of several cultural traditions." 19 Thus it is in his discussion of carnivals and carnival logic that he explores how the shared aspects of carnival culture, which travel from the Rio Carnival in Brazil, New Orleans' Mardi Gras and the Trinidad Carnival, is one that is ambivalent to the structures and strictures of official cultures. ${ }^{20}$ Nurse reveals how carnivals provide a cultural agency that loosens boundaries for diasporic populations.

Gender and women's cultural agency emerges as a theme across a number of essays that focus on gender as an important category for consideration of hybridity. Chapters such as Helen Kim's “Women Occupying the Hybrid: Second Generation Korean American Women Negotiating Choices Regarding Work and Family" and Tess Moeke-Maxwell's "Creating Place for Conflicted Space: Bi/Multi Racial Maori Women's Inclusion within New Zealand Mental Health" introduce women as actors in cultural identity formation. More explicitly and speaking directly to this discussion of identity and the African diaspora, the chapters by Fabienne Darling-Wolf and Salvador Vidal-Ortiz explicitly address the complexity and fluidity of hybridity. Both Darling-Wolf and Vidal-Ortiz examine the importance of a shift in the understanding of gender as an identity with multiple categories. However, what is most significant is that Darling-Wolf and Vidal-Ortiz go beyond considering gender dichotomies, they interrogate assumptions about biology and culture, and inevitably through their studies of immigration and globalization, respectively, Darling-Wolf and Vidal-Ortiz consider the assumed global culture of maleness and femaleness and further complicate our understanding of identity formation.

More specifically, Darling-Wolf considers the significance of gender bending and androgyny as an important part of the conversation on hybridity. She suggests that although analyses of hybridity are largely focused on racial dimensions and transnational relations, gender serves as an important site that can influence definitions of hybridity. She writes that the controversy surrounding debates of same-sex marriage, and intimacy in general, reveals, "how hybridi- 
ty can unsettle hegemonic constructions of gender."21 Grounding her chapter in Simone De Beauvoir's often cited statement "one is not born, but rather becomes, a woman," Darling-Wolf pushes back against the simplicity of a gender binary. She explores the significance of these individual acts of rebellion as acts that disrupt normativity and consequently function in broader cultural contexts to subvert assumed intimate structures. By concentrating on the changing legislation surrounding of same-sex relationships she demonstrates the potential to transcend conventional categories of identity, family and eventually culture.

While gender is broadly considered, Sharlene Hesse-Biber and Emily Brooke Barko use data gathered from interviews with young Black women to discuss the experiences of African American women in predominantly white colleges. In a chapter titled, "Neither Black nor White Enough - and Beyond Black or White: The Lived Experiences of African American Women at Predominantly White Colleges," Hesse-Biber and Brooke Barko open with an excerpt from an interview where a young Black woman, at a predominantly white college in the northeast United States, describes her experience of being an outsider in the assumed homogeneous Black population. In describing the young Black woman's experience, Hesse-Biber and Brooke Barko navigate a discussion with similar underpinnings to Tina Campt's work. Using their data on young Black women's experiences, they reveal the impact of making assumptions about identity, based on biology and like Campt they challenge the notion of a universally applicable model for understanding cultural formations of all Black populations.

The remaining chapters in the collection attend to themes of alienation, hybridity, and invisibility in relation to national identity and history. In "Occupying Third Space: Hybridity and Identity Matrices in the Multiracial Experience”, David L. Brunsma and Daniel J. Delgado use Bhabha's conceptions of hybridity as an 'in-between' term, referring to a 'third space', and to ambivalence and mimicry especially in the context of what might, uneasily, be called the colonial cultural interface. Bedelia Nicola Richards' chapter titled "Hybrid identities in the Diaspora: Second-Generation West Indians in Brooklyn" used data collected from interviews with twenty-four second generation West Indian youth in New York City. Richards is influenced by Yancey, Ericksen and Juliani $(1976)^{22}$ and their challenging the assumption that that "ethnicity among American ethnic groups is rooted in [the] groups' cultures of origin rather than in the ethnic communities that they recreate in the United States." ${ }^{23}$ Like Yancey et al, she resists this notion and asserts that although transnationalism shapes identity among immigrants who travel to the Caribbean often, identity is "an 'emergent phenomenon' cultivated from the unique social position of Brooklyn as the epicenter of West Indian Culture in New York City and the United States as a whole." 24 In this claim, Richards posits that although identities can survive generations, they shift and are adaptive in different contexts. 
This anthology provides an opening for the discussion of hybridity and it's role in identity and cultural politics. Although the text draws upon the global context, conversations about neoliberal politics and it's implications on identity formation appear anecdotal. The tone of the anthology appears to be ambivalent to the role of imperialism or colonialism in shaping hybridity. With the exception of references to critical thinkers such as Dubois, Bhabha, Gilroy and Hall, among others, the readers must be aware of the foundations of hybridity theory and the work of the aforementioned scholars in order to discern the obscure references to the processes that influence or encourage the movements that lead to hybridity. Specifically, based on Iyall Smith's discussion of differentiation, assimilation or hybridization in the opening paragraph of the anthology, imperialism, and colonialism appear obscure, implicit or simply absent and this sets the tone for the remainder of the book. From there, there is a sense that the reader is expected to consider differentiation, assimilation or hybridization apart from the forces that lead to the movement of bodies and the shifts in identities and cultures. By contrast, Leavy's introduction to the empirical section of the anthology masterfully introduces collective memory into the conversation about hybridity, while explicitly considering "the Other" and imperial. The anthology could perhaps be strengthened by foregrounding Leavy's perspective.

On the whole, the anthology's chapters carefully attend to the processes through which competing ideologies shape identity and culture over time.

Although, Iyall Smith and Leavy's use the concept of hybridity and signal to well known scholars in the field, their use of hybridity or hybrid identities and representations do not seem to be as fluid or dynamic as authors such as Bhabha or Hall have envisioned. Bhabha's argues that, "purpose in specifying the enunciative present in the articulation of culture is to provide a process by which objectified others may be turned into subjects of their history and experience."25

Nevertheless, this anthology strongly addresses the persistent presence of hybridity as a phenomenon resulting from cross-cultural encounters.

Hybridity is revealed as a challenge to fixed categorizations of identity. From this text, a variety of discourses of hybridity have surfaced across different traditions in order to control its meaning. This text is a good addition as it combines theoretical and empirical work to present studies of types of hybrid identities relevant to scholars interested in double consciousness, gender, diaspora, post-colonial and subaltern studies.

\section{Racial Political Formations}

The African diaspora in North America has been studied in multiple of contexts within the academy. Preston H. Smith II contributes to this scholarship through his book Racial Democracy and the Black. Metropolis. Historically, Chicago has held a central role in understanding the socio-political conditions of African Americans 
in the mid-west. The housing policy and its detrimental impact on African Americans in Chicago after the second world war has mostly been attributed to white elites and politicians. Smith's book is unique as it makes great strides in explaining the stratification of African Americans in Chicago in regard to identity, class, and political affiliations. Smith outlines a non-monolithic Black community in Chicago composed of working-class, middle income, and elite peoples. He also discusses the differing ideology of African American civic leaders, political elites, and the bourgeoisie. Smith critiques previous scholars reliance on over determining Cold War politics to fully explain the failure of Black elites to pursue a social democratic housing agenda. He argues, "that black civic leaders and policy elites had their own reasons for pursuing a racial politics that initially incorporated social democratic tenets, only to abandon the latter to accommodate a pro-business political economy." 26 Moreover, he suggests that Black elites are not wholly responsible for not confronting the reactionary postwar political pressures but, complicit in the reproduction of housing inequalities by negotiating their own pact with U.S. capitalism. ${ }^{27} \mathrm{He}$ does this by situating his analysis of Black elites within the schools of thought, which emerged from University of Chicago, as several leaders were scholars from this institution. Smith uses ten chapters to support the notion that Black elites in Chicago were complicit in their adoption of racial democracy, which subsequently perpetuated abysmal housing opportunities for working-class Blacks. Moreover, he asserts, that racial democracy was limited in its scope to offer a considerable critique to looming postwar capitalist ideologies. This book can be partitioned into four parts: chapters 1-3 provide historical context in addition to defining social and racial democracy, which enable a better understanding of Chicago's postwar political economy. Chapters 4-6 examine the impact of housing policies on African American citizens in Chicago. Chapters 7-8 discusses the challenges Black elites to white violence and race restrictive covenants. The last two chapters explore the negotiations of Black elites and private capital in regard to establishing house for Chicago's African American communities.

Smith uses a host of sources to support his claim. He uses a variety of secondary materials detailing race and Chicago politics. These include articles, newspapers, and annual report from the mayor's commission. Smith masterfully employs the use of Chicago Housing Authority documents to support his position. He methodically traces the evidence provided through previous research and arrives at a new interpretation. The materials are marshaled in a convincing fashion and reinforced by his inclusion of an updated review of the literature. The qualitative methodology of this work offers helps to complicate the previous assumption of Chicago's postwar politics, particularly, identifying and exploring the factions within the African American community. Using social and racial democracy as a framework to articulate the subtle and distinct differences in material outcomes for African Americans in Chicago is very insightful. Racial 
democracy focuses on civil liberties in addition to equal access to economic opportunities and social organizations for racial minorities, whereas social democracy advocated for access to economic opportunities and social organizations irrespective to racial designation. ${ }^{28}$ Smith suggests that the narrow scope of racial democracy stemmed the possibilities of improved conditions for most working-class families. The primacy of race consciousness served as a mantra to promote solidarity within the African American communities. ${ }^{29}$ In contrast, he asserts that, "only social democracy could content with postwar capitalism that had produced inadequate and unaffordable homes." 30 Although Smith recognizes some similar facets of social and racial democracy, he precludes the latter to be an inferior means to ameliorate inequalities produced and maintained through capitalist ideals. Again, he claims that, Black elites adopted capitalist policies, which correlated with the dominant American ideologies of the period equating homeownership as a means to demonstrate citizenship. ${ }^{31}$

The strict identity versus ideology dichotomy fails to fully acknowledge the overlaps and intersections, which could better explain the phenomenon being examined. Thus despite a seemingly artificial assignment, social democracy and racial democracy are interdependent yet are articulated in different ways due to the socio-political landscape. Smith notes that thirty percent of the population during the postwar era were "shelter poor" or working-class. In the book When Affirmative Action was White, Ira Katnelson argues that African Americans were disproportionately shelter poor and government programs did little to improve these conditions. The most prominent postwar policies that enhanced quality of life for working class Americans was social security and the G.I. Bill, which had a significant impact on housing markets throughout the country. Racial convents and customary discrimination typically prevented African Americans from accessing economic opportunities commensurate with their military service or income. These policies are recognized as the foremost initiatives, which improved living conditions for millions of working-class citizens in the postwar era. Rayford Logan and many other historians argue that leading into the 1950's working-class African Americans and those in poverty lived in unparalleled conditions within the United States. A discussion of these realities would have added to the complexities of Chicago's housing markets and aided the understanding of Black elites' political strategies and ideology.

Smith adds to our understanding of the African diaspora through the analysis of material outcomes for African Americans in Chicago during the postwar era. He describes political and racial formation constructs through ethnic pluralism and modernization theory. This theory was an attempt to explain the politics of newly independent countries of Africa and Asia. ${ }^{32}$ Modernization theory suggests that developing countries will eventually develop liberal capitalist economies similar to the West. The most striking similarity to this theory was the 
Black elites' reliance in postwar Chicago on a middle-class. The discussion of urban renewal, redevelopment, or slum clearance (gentrification) was at the center of debates regarding housing issues. An outcome was residents' collective action to conserve neighborhoods like Brozeville. ${ }^{33}$ They struggled to curtail the displacement of working-class African American families although alternative solutions or remedies to the abhorred living conditions were often at odds. ${ }^{34}$ However, the fight against restrictive covenants became a rallying point for quintessential middle-class reform. Smith suggests that the removal of restrictive covenants "thwarted liberal democratic values of individual choice and mobility." 35 The author provides detailed accounts of white violence to the enfranchisement of Blacks realizing the "American Dream." 36

The primary strength of this book is its unique approach to understanding the divisions within the Black communities in postwar Chicago. Smith is very detailed in categorizing the different elements, ideology, and identities that shaped the material outcomes for African American in Chicago residential markets. The foundation of this book rests on its ability to define and categorize ideology and identity; however, it reasons that these instances may be problematized further. In addition, the use of racial and social democracy allows for an alternative interpretation of the action and reactions of Black elites. Although this can highlighted as one of the many successes of the book these categorizations present some limitations. Moreover, the concession that the embrace of social democracy would not have change the structure of housing markets and policies without the crucial aid of organized labor and liberals, who already made their own Faustian bargains with cold-war capitalism."37 Therefore, the argument regarding social democracy as an alternative to racial democracy is rendered moot. Nevertheless, this is an exceptional survey of Chicago politics and provides insights to understanding the negotiations and strategy employed by African American elites during the postwar era.

\section{Conclusion}

In our essay, Transnational Perspectives: A Contemporary Examination of the African Diaspora, we undertook a project of synthesis and review, where we reviewed three books and focused upon the research of scholars of the diasporic experience to create one narrative of that discusses African diasporic populations. These texts, when read together, yield multiple layers of analysis-providing supplemental theoretical, historical and empirical backing in cases where it is required. It is in the confluence of ideas that these works illuminate the importance of more research on a topic that has long been neglected: the similarities and differences in the experiences of African diasporic populations and the heterogeneity of these identities and cultures. 
Hybrid Identities, helped us in our to consideration of the other two texts and specifically, in the negotiation of the multiplicity of identities in cultures that are often assumed to be monolithic. Although this text does not overtly discuss colonialism, slavery, and imperialism, it considered the effects of these influences in discussing hybrid identities. With the foregrounding hybridity, a term most often deployed by diasporic intellectuals from the so-called "Third World," living in Europe or the Americas, we purposefully discuss the multiplicity of cultural positions and perspectives of peoples of African descent. These works allow for the broadening of the discussion on African diaspora, without policing the borders of identity along essentialist and originary lines. Tina Campt's investigation into Afro-German culture, while situated in the larger context of the African diaspora, helps in this revelation. According to Campt's work, these similarities and differences occur simultaneously allowing for distinct cultural standpoints. Similar to her work, Image Matters, which focused on understanding Diaspora in Europe, Smith's Racial Democracy and the Black Metropolis also punctuates the significance of considering African diasporic populations as heterogeneous and fluid. Smith's insights into the stratification of African Americans in regard to identity, class, and political affiliations in Chicago opens up discussions about shifting cultural paradigms.

Read together with Iyall Smith and Leavy's text, both Campt's and Smith's work discuss the importance of a discourse on discussion of assimilation and dissimilation and the influencing factors. Although Hybrid Identities doesn't focus solely on people's of African descent, concepts and ideas grown from reading the anthology along with the other two texts can help develop conversations that provide important contributions to the literature on gender and the African diaspora while refuting the notion of a monolithic Black experience.

\section{NOTES}

1 Tina M. Campt, Image Matters: Archive, Photography, and the African Diaspora in Europe (Durham and London: Duke University Press, 2012), 7-8.

2 Ibid., 5.

3 Ibid., 31.

4 Ibid., 24.

5 Ibid., 112.

6 Ibid., 48-49.

${ }^{7}$ Ibid.,197.

8 Ibid., 135.

9 Ibid., 128. 
10 Ibid., 136.

11 Ibid., 197.

12 Paul Gilroy, The Black. Atlantic: Modernity and Double Consciousness (Cambridge: Harvard University Press, 1993).

13 Jacqueline Nassy Brown, Dropping Anchor, Setting Sail: Geographies of Race in Black Liverpool (Durham: Duke University Press, 2005).

14 W. E. B. Du Bois, Souls of Black Folk (Chicago: A. C. McClurg and Company, 1903).

15 Keri E. Iyall Smith and Patricia Leavy, eds., Hybrid Identities: Theoretical and Empirical Examinations (Chicago: Haymarket Books, 2008), 5-6.

16 Bill Ashcroft, Gareth Griffiths and Helen Tiffin. Post-Colonial Studies: The Key Concepts. (London: Routledge, 2003), 118.

17 Sara Ahmed "'She'll Wake up One of These Days and Find She's Turned into a Nigger' Passing Through Hybridity," Theory, Culture \& Society 16 (1999), 87-106; Stuart Hall, "Cultural Identity and Diaspora," in Identity: Community, Culture, Difference, Jonathan Rutherford, ed. (London: Lawrence and Wishart, 1990), 222-37; Arjun Appadurai, Modernity at Large: Cultural Dimensions of Globalization (Minneapolis: U of Minnesota P, 1996); Homi Bhabha, The Location of Culture (London: Routledge, 1994); James Clifford. "Diasporas," Cultural Anthropology, Further Inflections: Toward Ethnographies of the Future 9 (1994), 302-338.

18 Smith and Leavy ed, Hybrid Identities, 117.

19 Ibid., 118.

20 Ibid., 121.

21 Ibid., 67.

22 William L. Yancey, Eugene P. Ericksen, and Richard N. Juliani. "Emergent Ethnicity: A Review and Reformulation," American Sociological Review 41 (1976), 391-403.

23 Smith and Leavy ed, Hybrid Identities, 267.

24 Ibid., 268.

25 Bhaba., 20.

26 Preston H. Smith II, Racial Democracy and the Black Metropolis: Housing Policy in Postwar Chicago (Minneapolis: University of Minnesota Press, 2012), xvi.

27 Ibid., xii.

28 Ibid., 5.

${ }^{29}$ Ibid., 6.

30 Ibid., xiv.

31 Ibid., 22.

32 Ibid., 3. 
126 Byndom and Sanya

33 Ibid., 138.

34 Ibid., 41.

35 Ibid 30, 197.

36 Ibid., 175, 298.

37 Ibid., 298-299. 